\section{SCIENTIFIC RESEARCH AND DEVELOPMENT IN THE EMPIRE*}

\author{
By PROF. A. V. HILL, O.B.E., F.R.S., M.P.
}

\section{Canet}

$I^{\mathrm{T}}$ might seem a bitter irony of fate that a lecture should be given in memory of a great French engineer, in the field of artillery, who lived so long in England and had so many intimate connexions here, at a time when a Government of traitors in France is actively aiding the common enemy against her ally. Were Jean Baptiste Gustave Adolphe Canet alive to-day, we know very well where his heart would be. "It would be impossible", it has been said of Canet, "to record his innumerable acts of consideration and regard for the Junior Institution of Engineers", of which he was an honorary member, a vice-president, and president in the year he died. It would be impossible for an Englishman who has been intimate with Frenchmen of his kind not to believe that France will rise again, purged by her misfortunes, to better things. The world cannot do without a nation which can produce men of his genius, whether for engineering, philanthropy or friendship.

\section{Empire Science}

France, however, does not come very far into the story of scientific research and development in the Empire, which I have to tell to-day, though it is true that the Dominion of Canada was originally French, that a significant part of its culture is still French, that scientific men and engineers of French origin take an important part in Canada's life, and that Henri Laugier, head until the fall of France of the French equivalent of the Department of Scientific and Industrial Research, is busily engaged there now in work devoted to our common cause. Predominant as may be, so far, the Anglo-Saxon part in Empire science, significant contributions have been and are being made by almost every national group within it. It is a common enterprise of all the peoples of the Empire, biased locally in direction by local requirements and facilities, but carried on everywhere in the same spirit, by the same methods and with the same standards of accuracy and objectivity.

The chief object of this lecture will be to try to indicate how closer and more effective scientific co-operation within the Empire can be obtained.

\section{Imperial Collaboration in War Research}

In the early days of the War my colleague and co-secretary of the Royal Society, Prof. A. C. Egerton, and I, convinced of the enormous prospective advantage to our common war effort of close consultation with organized science in the Dominions, discussed the matter with Sir William Bragg, then president of the Royal Society, who, from his twenty-two years at Adelaide, was very well acquainted with science in Australia, and had close connexions with scientific men in the other countries of the Empire.

Fortunately, Dr. R. W. Boyle, of the National Research Council of Canada, was in London at the time-having escaped from Poland, where he had been on holiday when war broke out-and discussions

- Substance of the ninth quadrennial Gustave Canet Memorial Lecture of the Junior Institution of Engineers on May 22 . with him then helped to bring our plans to later fruition. That winter also, Dr. Madsen came to England from Australia to obtain information about certain important scientific and technical developments here which must be of vital importance now, with Australia in the front line of battle. Then early in 1940 the opportunity occurred of going for a period, on behalf of the Air Ministry, to the British Embassy in Washington; an opportunity which I seized, seeing in it the means of making arrangements for scientific collaboration, on the one part between Britain and the United States (not yet in the War, but warmly sympathetic), on the other part between Canada and the "old country", as they affectionately say. There was no difficulty of any kind in Canada -only anxiety to see the thing put through-and plans were accordingly made. In Washington one was confidently assured that the President would instantly respond to an approach from the British Government-which, in fact, he did when the approach was ultimately made.

In August 1940, the Canadian plan was started off by Prof. R. H. Fowler going to Ottawa to act as scientific liaison officer with the National Research Council, and to develop an informal connexion with scientific men in the United States. A little earlier the National Defense Research Committee had been formed in Washington, with Dr. V. Bush as chairman. Finally, in the autumn of 1940, Sir Henry Tizard took a mission to Canada and the United States. No words can overstress the importance of what was achieved by that mission and by Fowler's strenuous efforts.

In the meantime another plan we had had at the Royal Society, since the summer of 1938, also reached shape and fruition, and the Scientific Advisory Committee of the War Cabinet was formed-most fortunately under the chairmanship of Lord Hankey.

It is difficult now to remember good-humouredly the further unnecessary difficulties which arose, but finally an office of the National Defense Research Committee was established at the American Embassy in London and a British Central Scientific Office in Washington; while representatives of Canadian and Australian science were appointed to the offices of their High Commissioners in London. To these a continual flow of scientific men and engineers, engaged in various projects, has come; while in the persons of Mr. Nevill Wright, of the New Zealand office, and of Colonel B. F. J. Schonland, of South Africa, representatives of those Dominions also have been available in our counsels. Attempts have been made, but unsuceessfully so far, to establish similar arrangements with Indian science.

\section{Speed in Travel and Transmission}

The contributions which have been made already by this organized collaboration have been very important, and now that it is running sweetly greater results still will accrue. It is quite impossible to achieve more than a small fraction of what is needed merely by correspondence and by the circulation of reports, drawings and specifications: personal contact and personal initiative are needed also, for which it is necessary to provide, on the one hand permanent or semi-permanent scientific liaison officers in the various centres-as has now been done-on the other, means of rapid transport for short visits by experts either way. The rapid transfer also of correspondence, documents and drawings, and of small samples, is essential-for the former, given air transport, the 
microfilm method, which is rapidly coming into its own, is of very special advantage.

Great difficulty is still experienced from slowness of travel and transmission of scientific people and information. At present official communication with the United States may take anything from two to six weeks. It is too slow. With Australia and New Zealand and South Africa now it is essential that safe and rapid transfer of information should be possible.

\section{The Future}

The presence in London of so many representatives of science in the Empire, in close and frequent contact with their colleagues at home by visits and correspondence, offered the opportunity of instituting a discussion of joint problems, quite apart from those immediately connected with the War. The persons concerned would naturally be very busy with urgent work, but the question of future scientific collaboration within the Empire, and, arising from that, with the United States, was so important that a general consideration of it at occasional informal meetings would be possible and fruitful. The two main objects of discussion might be, first, emergency problems of the immediate post-war era, and, secondly, the possibility of making the most of our common scientific resources and heritage for improving both scientific knowledge itself and the life of the peoples of the Empire.

With this in view, the officers of the Royal Society called a conference in October 1941 of the representatives of the countries of the Empire, together with the officers of the Society, the secretaries of the Agricultural Research Council, the Medical Research Council, and the Department of Scientific and Industrial Research, and others. The president, Sir Henry Dale, in opening the conference, mentioned the ideal of continued collaboration in time of peace, saying that the material structure of society depends on science, and that if reconstruction was to be tackled on a properly international scale science must once more become an international activity. A first step towards this could probably best be taken on the initiative of scientific men of the British Empire and the United States together; for example, the Inter. national Scientific Unions would have to be started again, if possible on better lines. Sir John Madsen, from Australia, felt sure that great interest would be taken by the other Governments of the Empire in the view of the United Kingdom Government in this matter ; he suggested that an extension of facilities for meeting and working with their colleagues elsewhere would greatly improve collaboration, and that the first activity of a committee to be set up, following the conference, might be to explore the facilities at present available and the means of extending them. General A. McNaughton, as president of the National Research Council of Canada, offered every possible help and support for the objects of the conference, and considered that the interchange referred to should occur, not only between universities, but also between industrial and Government laboratories in the different countries, including if possible the United States: he did not believe that if scientific people were convinced that this interchange was necessary, financial difficulties need stand in the way. Sir Edward Appleton, secretary of the Department of Scientific and Industrial Research, hoped that permanent liaison officers would be maintained in scientific and technical matters in peace-time as well as war. Sir Henry Tizard foresaw financial stringency as regards interchange for educational purposes, as distinguished from specific research, but urged that exchange would be particularly valuable between the universities of the Empire during undergraduate years, especially in applied science.

Lord Hankey welcomed the calling of the conference and said he felt sure that during the explora. tory work proposed to be undertaken the inquiry would branch out and important new points of interest emerge. He referred to the advantage of having a scientific advisory committee with a Cabinet Minister as chairman, to bring science into direct contact with the centre of government. If in each country of the Empire the scientific organization was thus arranged, there would grow up gradually an official appreciation of science, since from time to time, as ministries changed, one Cabinet Minister after another would be taking a special interest in science. Colonel Schonland (South Africa) urged the importance of considering the scientific needs and possibilities of Africa as a unit; and he added in a later letter to me: "It is not a question of money at all, but of brains and sound organization."

A number of others took part in the discussion, and it was recognized that later on it would be most desirable if possible to secure close collaboration with official and unofficial science in the United States; all were agreed that popular lecture tours did not at all ful. fil the purpose in mind; special reference was made to co-operative work in agriculture; and the conference then appointed a committee to look into the various proposals made.

I have described the discussion at this conference in some detail because of the great importance of several of the points raised, because it may be the beginning of an important movement towards closer scientific collaboration, and because many in other parts of the world may be glad to know of what is going on. It is not easy in times like these to get much more work out of busy people, but the committee appointed (which, in addition to representatives of the Royal Society and of the Dominions and India, has included Sir David Chadwick, secretary of the Imperial Agricultural Bureaux) has met already seven times; and owing to the initiative of its secretary, Dr. Alexander King, scientific liaison officer in the Ministry of Supply, much information has been collected and discussed on science in the Empire and on facilities for interchange in advanced study and research. The representatives of a variety of interests have been interviewed, including the research associations, the Universities Bureau of the British Empire, the 1851 Exhibition Studentships, the Leverhulme Fellowships and the British Council; and a variety of suggestions have been made and followed up. All this will serve as the basis for further exploration and planning, and it is intended next to proceed to the discussion of concrete proposals to improve the machinery of collaboration.

\section{The Colonies}

In all this discussion there has been no specific reference so far to the Colonies, only to the Dominions and India. The scientific problems and the possibilities of scientific development in the Colonies, Protectorates and Mandated Territories are, however, of great importance, and considerable attention has, in fact, been devoted to them for some time. In 1927, for example, the Colonial Office formed a Colonial 
Medical Research Committee, a mixed body of administrators and scientific members. Little, however, was done, but in 1936 the Colonial Office asked the Medical Research Council to supervise research in tropical disease, a project which this time seemed likely to be highly successful, but was interrupted by the War. Under the Colonial Development and Welfare Act, 1940, two funds have now been created, one of $£ 5,000,000$ a year for ten years for Colonial development and welfare generally, one of $£ 500,000$ a year without time limit for Colonial research. A director of a proposed Colonial Products Research Institute, it is hoped, will shortly be appointed; the products in question are those of biological origin. A Colonial Research Advisory Committee is to be set up under the chairmanship of Lord Hailey, which will not only advise on the expenditure of $£ 500,000$ per annum, but also will "advise upon and co-ordinate the whole range of research in Colonial studies".

The Imperial Agricultural Bureaux, founded in 1929, are concerned with agricultural matters in the Colonies as well as in all the other countries of the Empire. The Imperial Institute, founded in 1887, has five main departments, dealing with the commercial, industrial and educational interests of the Empire, particularly in relation to raw materials, to research upon them and to the development of their use and supply ; minerals, plant and animal products, exhibition galleries, intelligence, statistics, library and laboratories are among its many activities. The Institute has many difficulties to contend with, not least the fact that with its enormous field of interest its annual budget is only $£ 48,000$, less than $1 d$. per square mile of the Empire whose natural resources it surveys, less than $3 d$. per square mile if calculated for the area of the Colonies alone!

\section{An Africa Research Council}

One of the suggestions made to the British Commonwealth Science Committee, to which I have referred, is that for the purposes of scientific research and development Africa might be treated as a separate unit, the work being a joint concern of the scientific organizations of the United Kingdom on the one hand and of the Union of South Africa on the other. Among the subjects to be treated, for which Africa as a whole has special needs and opportunities, might be tropical diseases, social anthropology and race relations, native languages, ethnology, geology, geophysics and meteorology.

The formation of an Africa Research Council, a joint interest both of governments and private benefactors and individuals, as so many of the best of our British institutions are, might lead to developments of the kind required for specifically African problems. There is no other region in the world in which the same variety of researches is needed, all to some degree for geographical and political reasons inter-related; if the different elements of this variety could be treated each as part of the whole scientific problem of Africa, and made to fit into the other elements, the results might be much more satisfactory and more far-reaching in importance than if all were studied separately according to subject and locality. A good example of the need for such an Africa Research Council is shown by the failure, before the War, to get a badly needed geodetic survey of Africa started, because there was no body in existence to father it.
It is clear that a scheme of this kind must wait for better times: it would involve the setting up of a central office and council, the collection and allocation of funds, the distribution of work and interests between it and other agencies, and the foundation of new or the development of existing research institutes, in Great Britain or in various parts of Africa. In view, however, of the obvious advantages it might have, it may be well to throw it now into the arena of discussion, so that on one hand it may be thought about, on the other so that no action may be taken in the meantime which might make it in the future more difficult to realize.

\section{Existing Scientific Agencies in the Dominions and India}

The scientific organization of the Dominions and of India is so highly developed, in universitios and research institutions, in industry and under Government auspices, that no account of it, valuable as one would be, could be given in a lecture. The National Research Council of Canada is the equivalent, roughly, of the Department of Scientific and Industrial Research and the Medical Research Council in Great Britain, and of the research departments in the Service and Supply Ministries. It has great resources and a magnificent record, particularly in the present War. In Australia, the Council for Scientific and Industrial Research is the approximate equivalent of our Department of Scientific and Industrial Research and under the able leadership of Sir David Rivett it has made very important contributions both in peace-time and for the defence of Australia in the last three years. In South Africa the National Research Council, with advisory functions, and the National Research Board, with administrative functions, together with the South African Institute for Medical Research, take a prominent part in scientific developments in the Union. In New Zealand the Scientific and Industrial Research Department plays an analogous role. In India, the Board of Scientific and Industrial Research, under the able directorship of Sir Shanti Swarupa Bhatnagar, has taken a very active part in mobilizing the scientific and technical resources of India since its foundation in 1940 ; the Survey of India, the Zoological Survey, the Botanical Survey and the Geological Survey, the Indian Science Congress and the Indian Research Fund Association (medical) all have obvious and important tasks to fulfil.

This is merely a selection for purposes of illustra. tion; Government agencies, universities, and private benefactions are responsible for innumerable others : in education and research; in application to defence, to industry and transport and to medicine and public health; in agriculture ; for improving knowledge on one hand and the life of the people on the other. In each of these countries science and the scientific outlook, research and its application, make up a great and living organism. No doubt in each of them much remains to be done, as it does in Great Britain ; but what is chiefly needed, and what will help beyond any other single factor in forwarding the promotion of science itself and its application to the public welfare is closer contact, more intimate knowledge, quicker and more frequent communication, a better intelligence and information service, easier exchange, between the several living parts of the whole living organism of science spread across the Empire, andI should like to add--the United States. 


\section{Freedom of Research}

I have talked a good deal about co-operation and collaboration, but not-you may have noticedabout co-ordination. Science is a free growth, and, as Sir David Chadwick recently wrote in a note to the British Commonwealth Science Committee: "much of the most valuable research must be free . . . To many who rightly prize that characteristic of research, the word 'co-ordination' denotes 'sinning against the Holy Ghost'. . . . One must bear in mind that the countries in the British Commonwealth have developed on different lines. These lines may meet in the end, but their starting points have been poles asunder."

This warning must be remembered. Co-ordination is necessary, within limits, to help to guide research into profitable channels and lest waste, overlap or its converse may occur; but in dealing with a group of proud and independent nations, however friendly and co-operative, we and they must all beware of attempting to introduce a degree of direction, authority or control which many will certainly resent. The Imperial Agricultural Bureaux represent an ideal of equal partnership in the co-operative dissemination of information on research. There is no reason why similar collaboration should not be built up about similar bureaux in other scientific subjects, or, for example, around the libraries and information services of the industrial research associations, the Imperial Institute, or other similar bodies in Britain or the Dominions. London need not necessarily, be the focus for all. Co-ordination will then come naturally with increase of knowledge, contact and information. Co-operative research is a living, growing organism; it must be carefully tended, not just pushed into a mechanical framework planned from outside.

We hear a good deal about planning, and planning of scientifie research we must certainly have. An Africa Research Council, for example, if it were to be set up, would require a deal of planning. Freedom, on the other hand, is the material and moral basis of the British Commonwealth, and requires explicit recognition in all we do or say. In some way planning and freedom must be combined. There is in this, as in most human affairs, an optimum mixture, the right proportions of which we must seek and find. This optimum must be aimed at, here in Britain, in the action and reaction of free science and free initiative with seience and initiative provided by the State. It must be aimed at independently, perhaps with a different final mixture appropriate to their conditions, in each of the countries of the Empire; and it must be sought in the freely accepted co-ordination of the scientific activities of the.different parts of the whole Commonwealth.

My own faith is that improvement in knowledge, contact, communication, familiarity between the scientific people of the Empire-and of the United States-will allow that co-ordination quietly to bo achieved, the planning to be successfully undertaken, without any violation of the freedom on which we all set so great store, about which we are all so sensitive. It comes back again, therefore, to quickness, ease and facility of travel, transport and communication-things which engineers, in one way or another, must provide. For I believe that scientific people-and engineers-are on the whole rather more reasonable and practical-if not very much-than other folk, and that when we get to know each other by working together on a common job, we are generally ready to appreciate and understand the other fellow's difficulties and virtues and his point of view. The common job exists obviously enough in the scientific development of the Empire, for the improvement, as I repeat, of knowledge and of the life of its people : the important thing therefore is to improve the methods and technique of getting down to it together.

\section{FAMILY ALLOWANCES BY D. CARADOG JONES University of Liverpool}

$\mathrm{T}$ HE subject of family allowances-assistance given in cash rather than in kind, to meet the cost of maintaining children during the period of their dependency-bids fair to become a live political issue. It is now nearly twenty years since Miss Eleanor Rathbone's much-debated book, "The Disinherited Family", was published, wherein she made a powerful and piquant plea for the introduction into Great Britain of some system of communal payment for the important task of rearing children. Other countries had seized the opportunity presented by the War of 1914-18 to slip in the thin edge of the wedge and the breach thus made was afterwards widened, but Great Britain allowed that chance to pass.

It may seem odd that a time of war should be considered appropriate even for the discussion of such a subject. There are several reasons to account for it. When things are upside down, people are more ready to listen to revolutionary proposals. By grafting on to the normal bargaining process for settling wages a scheme of children's allowances, the needs of the family are taken into account as well as the skill and merit of the worker. To accomplish this would clearly be difficult unless prices are rising, and they invariably do rise during wars; and if wages are to keep step with the cost of living, there is much to be said for a sliding scale graduated according to the number of mouths to be fed. The payment of war-time separation allowances encourages, too, a widespread habit of expecting the weekly income to conform to the size of family. Moreover, under war conditions, the unmarried young man, if left to earn good money by making munitions instead of being obliged to serve in the Forces, would be unlikely to wish to attract critical attention by complaining if his pay does not rise in the same proportion as that of the man with a family.

Trades union leaders in Great Britain have in the past been either antagonistic or only lukewarm in their attitude towards family allowances, largely from a fear that they might be used to depress their standard of living. In countries such as France and Belgium there was the same fear, but it did not persist in any marked degree after the introduction of a compulsory State system covering a large proportion of the employed population. Under the type of scheme favoured by these countries, the allowances were financed by equalization funds, to which contributions were made by all the employers engaged in a specified industry or resident in a defined region. The sum put into the pool by each employer was proportional to the number of his workers or to his total wages bill. This simple device overcame the difficulty that some firms might otherwise have been tempted to employ only single men or men with very small families. 